\title{
Szkoła na miarę czasów... tylko których? - o reformie szkolnictwa z 2017 roku
}

\author{
A school for the times... but which times? \\ - about 2017 school education reform
}

\author{
Katarzyna Błaszczyk
Uniwersytet Jagielloński, Kraków
ORCID: 0000-0002-8798-3446
}

\begin{abstract}
The subject of this article is an analysis of the 2017 education reform and assessing whether this reform addresses the needs of the modern student. The problems of the education sector are discussed in the report from the last edition of the PISA survey and the results of own research. The quoted data presents the student's perspective on the functioning of schools and on the enrollment in the core curriculum for the Polish language. The article also contains a summary of characteristic elements of the previous education reforms (with particular emphasis on the Jędrzejewicz reform). This review allows to assess the level of innovation of recent changes and the validity of duplicating previous solutions. The analysis of the current core curriculum is the starting point for determining the current direction of educational policy. Thanks to this, it is possible to estimate how much the reformers' proposals are able to stop the problems of the modern school and to what extent they can become a source of further difficulties.
\end{abstract}

Key words: reform, core curriculum, PISA

Streszczenie: Artykuł poświęcony jest analizie reformy szkolnictwa z 2017 roku pod kątem jej przystawalności do potrzeb współczesnego ucznia. W celu nakreślenia trudności, z jakimi zmaga się sektor edukacji, wykorzystano raport z ostatniej edycji badania PISA oraz wyniki własnej próby badawczej. Przytoczone dane prezentują spojrzenie uczniów na funkcjonowanie ich szkół oraz podstawę programową z języka polskiego. Tekst zawiera również zestawienie charakterystycznych elementów poprzednich reform (przede wszystkim reformy Jędrzejewiczowskiej). Przegląd ten umożliwia ocenę poziomu nowatorstwa ostatnich zmian oraz zasadności powielania wcześniejszych rozwiązań, a analiza obecnej podstawy programowej staje się punktem wyjścia do nakreślenia bieżącego kierunku polityki oświatowej. To w dalszej kolejności pozwala oszacować, jak bardzo propozycje reformatorów są w stanie zahamować aktualne problemy, w jakim stopniu zaś mogą stać się źródłem kolejnych.

Słowa kluczowe: reforma, podstawowa programowa, PISA

W 2017 roku w życie weszła reforma oświaty, która w znaczący sposób zmieniła strukturę szkolnictwa, przywracając jego dwustopniowy podział 
obowiązujący od 1968 do 1999 roku. Ostatnie przeobrażenie zniosło zatem najistotniejsze postanowienia reformy ministra Handkego. Ocena ostatnich decyzji Ministerstwa Edukacji Narodowej (tj. nie tylko przywracających ośmioklasową szkołę podstawową, wydłużających okres nauki w szkołach średnich, ale także wprowadzających znaczące zmiany w podstawach programowych) opiera się głównie na dokonywaniu porównań między tymi dwiema, niezwykle zróżnicowanymi wizjami polskiej oświaty (Dorczak 2019, Krawiec 2018, Karkut 2019). Czy jednak ta zmiana sprzyja budowaniu nowoczesnej, efektywnej i bezpiecznej szkoły? Czy jej twórcy wykazali się innowacyjnością lub też skorzystali z cennych lekcji pozostawionych im przez ich poprzedników? Czy właściwie ocenili przystawalność wcześniejszych propozycji do potrzeb współczesności?

Wszystkie przemiany szkolnictwa powinny być analizowane dwutorowo: jako odpowiedź na przekształcenia w wymiarze społecznym, politycznym i gospodarczym, a także jako ich najważniejszy fundament. Niezmiennie bowiem podstawowym zadaniem szkoły pozostają: wychowanie młodych ludzi oraz wyposażenie ich $\mathrm{w}$ wiedzę i umiejętności, ponieważ to właśnie uczeń, jako główny podmiot procesu nauczania, po jego zakończeniu w mniejszym lub większym zakresie stanie się odpowiedzialny za kształtowanie rzeczywistości (jako np. pracownik, działacz polityczny, dydaktyk czy chociażby rodzic). Dlatego właśnie sposób organizacji systemu oświaty, będący jednocześnie odzwierciedleniem obecnych oraz generatorem przyszłych potrzeb i wyzwań na gruncie każdej dziedziny życia, nie może być analizowany w oderwaniu od kontekstu historycznego. Nie inaczej należy rozpatrywać także współczesne przemiany polskiego szkolnictwa.

\section{Równe szanse jako wstęp do integracji społeczeństwa}

Bez wątpienia za moment przełomowy dla naszego kraju należy uznać rok 1918, czyli odzyskanie po 123 latach niepodległości. Wówczas najważniejszym wyzwaniem okazała się konieczność zespolenia trzech zróżnicowanych pod względem politycznym, ekonomicznym, społecznym i kulturowym dzielnic pozaborowych. Było to o tyle trudne, że wiązało się z ogromnym zacofaniem cywilizacyjnym, któremu sprzyjał chociażby brak obowiązku szkolnego na terenie zaboru rosyjskiego, a w konsekwencji także analfabetyzm. Równie osłabiające dla funkcjonowania wyzwolonego kraju były skutki działań wynarodawiających (Korzeniowska 2004, Wnęk 2008). W obliczu tego wyzwania niezwykle istotną rolę przypisywano szkolnictwu. Obowiązek odbudowy systemu oświaty spoczął zatem na władzy państwowej - a dokładniej na Ministerstwie Wyznań Religijnych i Oświecenia Publicznego (Magiera 2018).

Gwarancję realizacji postulatu integracji zróżnicowanego społeczeństwa miało przynieść osadzenie szkolnictwa na jednym stabilnym fundamencie - funkcji wychowawczej szkoły rozumianej wówczas jako dążenie ku 
odrodzeniu moralności publicznej i budowanie postawy dobrowolnej odpowiedzialności za wspólnotę narodową. Urzeczywistnienie tejże wizji sektora edukacyjnego mogło powieść się jedynie wówczas, gdyby w działania integrujące zostali włączeni wszyscy obywatele, niezależnie od pochodzenia społecznego, statusu majątkowego czy światopoglądu (Grzywna 1975). W tym celu w 1919 roku wprowadzono dekret o obowiązku szkolnym, co wiązało się także z bezpłatnością i dostępnością szkolnictwa dla wszystkich dzieci od 7 do 14 roku życia. Powyższe przekształcenia ugruntowała dodatkowo Konstytucja marcowa z 1921 roku, nakładając na wszystkich obywateli obowiązek kształcenia w szkole powszechnej i gwarantując darmową naukę w szkołach państwowych i samorządowych (Ustawa z dnia 17 marca 1921 r., art. 118 i 119), a gminy zobligowano do założenia placówek oświatowych w przypadku, gdy ich teren zamieszkiwało co najmniej 40 dzieci we wspomnianym przedziale wiekowym (Osiński 2018, 11).

Wspomniana szkoła powszechna w ramach Ustawy o ustroju szkolnictwa z 1932 roku (zwanej potocznie „reformą Jędrzejewicza” - ówczesnego Ministra Wyznań Religijnych i Oświecenia Publicznego) została podzielona na trzy stopnie. Pierwszy, czteroletni miał otworzyć przed uczniem możliwość kontynuowania nauki w ramach drugiego stopnia w szkole powszechnej lub najniżej zorganizowanej szkole zawodowej. Absolwenci drugiego, dwuletniego stopnia zyskiwali zaś możliwość rozpoczęcia kształcenia w czteroletnim gimnazjum, a następnie w dwuletnim liceum. Nowa struktura ogólnokształcącej szkoły średniej umożliwiała rozpoczęcie kształcenia na studiach wyższych wszystkim absolwentom, co otwierało nową perspektywę także dla osób pochodzących z niższych warstw społecznych (Grabowska 1969, 132). Same założenia nowej szkoły niosły zatem nadzieję na wyrównanie szans edukacyjnych. Należy przyznać, że poziom wykształcenia obywateli wskutek ustawy z 1932 roku zdecydowanie wzrósł, wciąż jednak w wyścigu o wiedzę dzieci z terenów wiejskich były poszkodowane. Kryzys finansowy oraz chroniczny brak miejsca w szkołach najczęściej zmuszał je do zaprzestania nauki na pierwszym lub co najwyżej trzecim stopniu szkoły powszechnej. W ten sposób wielu absolwentów wiejskich placówek wpadało $\mathrm{w}$ „ślepą uliczkę” bez możliwości kontynuowania edukacji (Grabowska 1969, 127). Uczeń po siedmiu latach szkoły powszechnej zyskiwał natomiast elementarne wykształcenie gospodarcze, społeczne i polityczne, jakie miało przygotować go do roli odpowiedzialnego i zaangażowanego w kształtowanie wspólnoty obywatela. Wychowanie społeczno-obywatelskie stało się bowiem jednym z głównych komponentów programowych „jędrzejewiczowskiej" szkoły.

Reforma Jędrzejewicza, choć niepozbawiona wad, wyrosła z trafnej diagnozy głównych problemów powojennej rzeczywistości, dzięki czemu doprowadziła do zmniejszenia analfabetyzmu, podniosła poziom kształcenia nauczycieli, a przede wszystkim potwierdziła formacyjny potencjał szkoły. Kolejne wydarzenia historyczne gwałtownie zahamowały dalsze prace nad 
poprawą polskiego sektora oświaty. Polityka okupacyjna Niemiec podczas II wojny światowej doprowadziła do likwidacji niemal wszystkich szkół powszechnych, średnich i wyższych na terenach wcielonych do Rzeszy. Co prawda wciąż funkcjonowały placówki znajdujące się w Generalnym Gubernatorstwie, jednak dotknięte działaniami germanizacyjnymi niewiele miały już wspólnego z wizją polskich reformatorów z dwudziestolecia międzywojennego. Podobny los (zniesienie polskich programów nauczania czy zmiana języka wykładowego na język okupanta) spotkał szkoły na terenach znajdujących się pod władzą Związku Radzieckiego (Osiński, 2018).

Po zakończeniu II wojny światowej w Polskiej Rzeczpospolitej Ludowej ukształtował się monocentryczny system władzy, a wraz z nim ujednolicone programy nauczania, służące nie zniwelowaniu konfliktów wewnątrz społeczeństwa, ale podporządkowane wychowaniu kolejnych pokoleń w służbie jedynej słusznej ideologii. Próba powrotu do rozwiązań zainicjowanych przez Jędrzejewicza nastąpiła pod koniec lat 90. XX wieku, kiedy to po dokonaniu szeregu przekształceń w sektorze administracyjnym i gospodarczym, nową strukturę zyskało także polskie szkolnictwo. Powołanie gimnazjów podyktowane było przede wszystkim chęcią ograniczenia wyraźnej dysproporcji w poziomie kształcenia w placówkach wiejskich i miejskich. Liczono na to, że gimnazja, których miało być stosunkowo niewiele (jedno w każdej gminie wiejskiej), pozytywnie wpłyną na osiągnięcia edukacyjne dzieci z małych miejscowości, przez co ośmielą je do podjęcia dalszej nauki $\mathrm{w}$ liceach, a następnie na studiach wyższych. Inicjator reformy gimnazjalnej, Mirosław Handke, przyznał, że inspirację dla jego działań stanowiła właśnie koncepcja z dwudziestolecia międzywojennego, ale poza przywróceniem zmienionej nieco ówczesnej struktury szkolnictwa, kierował się także chęcią integracji uczniów w okresie adolescencji oraz wydłużenia obowiązku szkolnego (Handke 2019).

Badania PISA dowodzą, że po tej reformie szkolnictwa poziom umiejętności piętnastolatków zarówno z dużych miast, jak i ze wsi uległ znaczącej poprawie. Od 2000 roku wyniki polskich uczniów w dziedzinie czytania wzrosły o 33 punkty, zaś od roku 2006 utrzymują się na poziomie co najmniej 500 punktów. Z całą pewnością warto docenić sukces gimnazjów, pamiętając jednocześnie, że jednak nadal uczniowie szkół wiejskich rzadziej niż ich rówieśnicy z dużych miast uzyskują najwyższe wyniki.

Należy zwrócić uwagę, że osiągnięcia piętnastolatków ze szkół miejskich naznaczone są znacznie wyraźniejszą dysproporcją. Wynika to prawdopodobnie z silniejszej konkurencji między placówkami w większych miejscowościach. W tej kwestii nie bez znaczenia pozostaje status społeczno-ekonomiczny. $\mathrm{W}$ mniejszych miejscowościach bowiem nie dostrzega się tak wyraźnego podziału na bogate i biedniejsze dzielnice, który sprzyja zróżnicowaniu poziomów szkół. W dalszym ciągu do rozstrzygnięcia pozostają wątpliwości, czy rozpiętość wyników jest konsekwencją zróżnicowania szkół podstawowych oraz jakie znaczenie wobec tego zjawiska ma

\section{Polonistyka. Innowacje}

Numer 12, 2020 
status społeczno-ekonomiczny (Sitek 2019). Dopiero pogłębienie diagnostyki w tej materii stanie się podstawą dla opracowania kolejnych, skuteczniejszych strategii, niwelujących nierówności edukacyjne ${ }^{1}$.

W roku szkolnym 2018/2019 przywrócona po niemal 20 latach ośmioklasowa szkoła podstawowa wypuściła w świat swoich pierwszych absolwentów, stawiając przed nimi poważne wyzwanie. Uczniowie, ubiegając się o miejsce w szkole średniej, w większym stopniu niż dotychczas musieli nie tylko sprostać rozległym wymaganiom rekrutacyjnym, ale także wyróżnić się spośród wyjątkowo licznej grupy konkurentów (nie tylko rówieśników, ale także starszych kolegów kończących w tamtym czasie gimnazjum). W ten sposób zauważalny stał się wpływ aspektu ekonomicznego na kształtowanie się szans edukacyjnych.

Podczas badań, które prowadziłam w tym szczególnym roku szkolnym², wielu ósmoklasistów oznajmiło, że z powodu niepewności o zadowalający wynik egzaminu zdecydowali się skorzystać z korepetycji. Do takiej praktyki przyznało się 82 (23\%) ankietowanych. W prywatne lekcje inwestują przede wszystkich rodzice uczniów szkół publicznych (24\%) i miejskich (28\%). Nieco niższy odsetek w placówkach prywatnych (20\%) prawdopodobnie wynika z wyższego poziomu kształcenia - rodzice decydują się opłacać czesne tam, gdzie czują się spokojni o rzetelne przygotowanie dziecka do egzaminów. Najmniejszą liczbę osób korzystających z korepetycji odnotowałam w placówkach wiejskich (15\%), co wynika być może z ograniczonej dostępności do tego typu wsparcia oraz nieco innych aspiracji zarówno rodziców, jak i samych uczniów. Liczby te, zważywszy na fakt, że dotyczą szkoły podstawowej, wydają się co najmniej niepokojące i wystawiają systemowi kształcenia oraz obowiązującym wymaganiom egzaminacyjnym niechlubne świadectwo. Rzecz jasna, selekcyjność już na tym etapie musi mieć miejsce, nie powinna być jednak warunkowana statusem społeczno-ekonomicznym, ale indywidualnymi predyspozycjami każdego ucznia.

Cofając się o sto lat w historii polskiego szkolnictwa, łatwo dostrzec, że potrzeba wyrównania szans edukacyjnych dzieci z różnych regionów Polski nie jest niczym nowym, choć naturalnie przyczyny tych nierówności były wówczas zdecydowanie odmienne od tych, z którymi zmagamy się obecnie. Szkolnictwo z dwudziestolecia międzywojennego w dużym stopniu osiągnęło cel, opierając swoje funkcjonowanie na swoistym paradoksie. Choć rodzące się w owym czasie koncepcje pedagogiczne (zawdzięczamy je przede wszystkim Januszowi Korczakowi, Henrykowi Rowidowi czy Helenie Radlińskiej) znacznie bardziej niż wcześniej akcentowały podmiotowość

\footnotetext{
${ }^{1}$ Nieco szerzej (z uwzględnieniem nauczania przedszkolnego) zagadnienie nierówności edukacyjnej zostało rozpatrzone w raporcie P. Sadury, 2012, Raport Fundacji Amicus Europae Szkoła i nierówności społeczne. Diagnoza zjawiska i propozycja progresywnej polityki edukacyjnej $w$ Polsce, Warszawa, http://www.feswar.org.pl/fes2009/pdf doc/raport-3.pdf (dostęp: 24.10.2020).

${ }_{2}$ Badania przeprowadziłam na przełomie lutego i marca 2019 r. Były one oparte na wypowiedziach ankietowych 346 uczniów oraz wywiadach z 12 nauczycielami z różnych typów szkół z różnych regionów Polski. Badania miały na celu zdiagnozowanie trudności w realizacji nowej podstawy programowej oraz sposobu przygotowań i nastroju polonistów i ich podopiecznych na krótko przed pierwszym egzaminem ósmoklasisty.
} 
dziecka w procesie nauczania i uwzględniały jego potrzeby, to obowiązek szkolny dotyczył każdego bez wyjątku. Ten pierwiastek przymusu okazał się jednak niezbędny w osiągnięciu najważniejszego celu - ujednolicenia kraju naznaczonego długotrwałymi działaniami wynarodowiającymi, zapóźnieniem cywilizacyjnym oraz deficytami edukacyjnymi, które przyczyniły się do powstawania różnic społecznych i kulturowych między poszczególnymi dzielnicami pozaborowymi. Osłabić je miało wychowanie w duchu troski o wspólną ojczyznę (Magiera 2018).

\section{Na straży jednomyślności - o dążeniach obecnych reformatorów}

Budowanie tożsamości narodowej jest także głównym komponentem Podstawy programowej z 2017 roku. Postulat ten został wyraźnie zaakcentowany nie tylko w wyborze lektur obowiązkowych, ale już w preambule. I dzisiaj nie do przeceniania jest zjednoczenie niezmiernie podzielonego polskiego społeczeństwa. Należy się jednak zastanowić, czy środki, które proponują autorzy nowej podstawy, są najwłaściwsze. Krzysztof Biedrzycki w ostatnich zmianach dostrzega pewne zagrożenie dla wspólnego kodu kulturowego:

To prawdziwa kwadratura koła: z jednej strony twórcy nowej podstawy stawiają sobie ambitny cel stworzenia wspólnego kodu kulturowego, z drugiej - duża część proponowanych przez nich lektur narzuca młodemu pokoleniu język ich rodziców czy nawet dziadków. Nie myślę tu o klasyce, ale o pozycjach z literatury dziecięcej i młodzieżowej. Czy kodem kulturowym ma być książka, która podobała się babci? Czy bez jej znajomości dziecko z babcią nie nawiąże kontaktu? Takie rozumowanie oparte jest na głębokim nieporozumieniu. Zwłaszcza że celem czytania we wczesnych latach edukacji ma być samo czytanie, a nie wpajanie dzieciom nie dość precyzyjnie zdefiniowanego kodu kulturowego (Biedrzycki 2017).

Jak już wcześniej wspomniano, instytucja szkoły ma wpisany w swoją naturę przymus. Na tej samej zasadzie odbywa się także kontakt ucznia z kanonem lektur. Biedrzycki zwraca uwagę, że arbitralność obcowania z literaturą na lekcjach języka polskiego powinna jednak służyć jedynie (lub aż) kształtowaniu nawyków czytelniczych, nie może zaś wynikać z chęci zaszczepienia konkretnego światopoglądu. Szanse powodzenia takiej praktyki wydają się zresztą niewielkie. Kanon, nawet w zestawieniu z podanym odgórnie „słusznym” odczytaniem, nie wystarczy do autentycznego zakorzenienia w uczniu poszanowania dla tradycji. Badacz nie postuluje rzecz jasna odejścia od kanonu, ale proces budowania tożsamości narodowej rozumie raczej jako podkreślenie atrakcyjności naszego dziedzictwa kulturowego, nie zaś jako organizowanie „kolejnych akademii ku czci”.

Biedrzycki wskazuje również na jeden z podstawowych problemów w obrębie zaproponowanej listy lektur. Powrót do klasyki wydaje się niewystarczający do zaszczepienia w młodych ludziach patriotyzmu. Co więcej, sprowadzenie największych dzieł polskiej literatury wyłącznie do roli narzędzia mającego wpoić miłość do ojczyzny (w tym miejscu rodzi się kolejne pytanie: czy miłość może być w jakikolwiek sposób wywołana przymusem?) 
w znacznym stopniu ogranicza ich potencjał. Teksty te bowiem stanowią doskonały punkt wyjścia dla dyskusji o przemianach w I RP czy różnych sposobach postrzegania polskości (Biedrzycki 2017).

Uczniowie podzielają jego sceptycyzm wobec powrotu do dawnych dzieł polskiej literatury. Prowadząc badania ankietowe wśród pierwszych ósmoklasistów, poprosiłam m.in. o wskazanie najbardziej nielubianej przez nich lektury:

\section{Tabela 1.}

\begin{tabular}{|l|c|}
\hline Tytuł & Liczba głosów \\
\hline Mickiewicz, Pan Tadeusz & 30 \\
\hline H. Sienkiewicz, Quo vadis & 28 \\
\hline S. Żeromski, Syzyfowe prace & 24 \\
\hline A. Fredro, Zemsta & 21 \\
\hline Mickiewicz, Dziady & 14 \\
\hline J. Słowacki, Balladyna & 10 \\
\hline Z. Krasicki, Żona modna & 8 \\
\hline J. Kochanowski, Treny & 7 \\
\hline A. de Saint-Exupéry, Mały Książę & 6 \\
\hline J. Kochanowski, Fraszki & 5 \\
\hline
\end{tabular}

Część uczniów nie udzieliła odpowiedzi lub podała więcej niż jeden tytuł Uwzględniono wyłącznie wypowiedzi uczniów, którzy zadeklarowali przeczytanie całej lektury

Jak łatwo zauważyć, respondenci z najmniejszym entuzjazmem odnoszą się przede wszystkim do pozycji XIX-wiecznych, które zmonopolizowały aktualny spis lektur obowiązkowych. Przyczyną niechęci uczniów jest w dużej mierze trudność w pokonaniu bariery językowej, jaką stawia przed nimi tekst. Za nie mniej ważny należy jednak uznać brak identyfikacji z bohaterami, a co za tym idzie - niemożność doświadczenia pełnego i satysfakcjonującego spotkania z książką.

[Najmniej podobała mi się książka Quo vadis] bo była za długa, mozolna, nudna i nie powinna być omawiana w 8 klasie tylko w liceach (była za trudna).

(o Syzyfowych pracach) Mimo iż ta lektura ukazuje trudne czasy zaborów i problemy z rusyfikacją nie miała w sobie takiego czegoś, aby chciało się ją czytać.

[Nie podobały mi się Syzyfowe prace], ponieważ była to nudna lektura i moim zdaniem nie nauczy nic innego człowieka.

(informacja dodatkowa, dotyczącą lektury uzupełniającej Hobbit, czyli tam i z powrotem) Powiew świeżości, lepsze niż starocie pisane enigmą. ${ }^{3}$

\footnotetext{
${ }^{3}$ Wszystkie wypowiedzi uczniów są przytaczane w oryginale i pochodzą z ankiet będących częścią badań własnych.
} 
Jak pokazują powyższe przykłady, próba zaszczepienia nastolatkom modelu patriotycznego reprezentowanego przez literaturę XIX wieku okazała się nieskuteczna. Uczniowie żyjący w zupełnie innej epoce, naznaczonej postępem technologicznym, także globalizacją wzorców kulturowych, nie pojmują już motywacji postaci uciemiężonych przez zaborcę lub prześladowanych z powodu wyznania. Nie jest to kwestia braku wrażliwości. Wielu moich respondentów wyraziło bowiem szczere wzruszenie losami Zośki, Alka i Rudego z Kamieni na szaniec, a lektura powieści skłoniła ich do pogłębienia wiedzy na temat II wojny światowej. Rzecz jasna, nauczyciel nie powinien rezygnować z przybliżania uczniowi odleglejszej historii, trudno jednak nie posiłkować się przy tym literaturą współczesną. Rynek wydawniczy z myślą o młodym odbiorcy co roku dostarcza przecież nowych, adekwatnych do tego celu wartościowych pozycji ${ }^{4}$. Niestety, twórcy ostatniej Podstawy programowej z języka polskiego w szkole podstawowej nie pozostawili przestrzeni dla ich analizy i interpretacji.

Andrzej Jędrzejewski i Marek Cichocki zauważyli, że patriotyzm obecnie utożsamiany jest przede wszystkim z narracją patetyczną i martyrologiczną typową właśnie dla wielu utworów XIX-wiecznych. Nie ulega wątpliwości, że taki sposób postrzegania polskości to istotna część kultury. Badacze zwracają jednak uwagę, że ten model patriotyzmu nie przystaje już do warunków życia w XXI wieku i wymaga przedefiniowania, by funkcjonował w zgodzie z demokratycznymi ideałami (Gałaś 2020).

Koncepcje kształcenia nie mogą powstawać obok rzeczywistości, w której istnieje nauczyciel i uczeń, z wszystkimi charakterystycznymi dla ich rzeczywistości uwarunkowaniami, typowymi dla kultury XX i XXI wieku. Nie cofniemy czasu do okresu, który wydaje się nam optymalny (Tomaszewska 2016).

System oświaty nie może zatem funkcjonować w oderwaniu od aktualnych realiów politycznych, gospodarczych czy społecznych. Jeśli ma przygotować ucznia do płynnego wejścia w dorosłe życie, musi uwzględniać w procesie kształcenia możliwości i problemy, z jakimi lada moment przyjdzie mu się zmierzyć. Nie może zatem ignorować dzisiejszych coraz wyraźniejszych podziałów społecznych i powszechnej wzajemnej niechęci wynikającej z rozmaitych różnic światopoglądowych. Aktualne wyzwania edukacyjne zdradzają pewnie podobieństwo do sytuacji z początku XX wieku. Geneza obecnych napięć kształtuje się jednak nieco inaczej. Konflikty społeczne nie są już pokłosiem przemyślanego procesu wynarodowienia, ale postępującej globalizacji, podniesienia rangi organizacji międzynarodowych, a co za tym idzie - także zniesienia barier w przepływie ludności między granicami państw.

Jak podaje Urząd do Spraw Cudzoziemców, w Polsce przebywa obecnie ok. 451000 imigrantów, w tym głównie narodowości ukraińskiej (UdSC

\footnotetext{
${ }^{4}$ Wśród nich na uwagę zasługuje chociażby seria wydawnictwa Literatura pod tytułem Wojny dorosłych - historie dzieci, trylogia Mariusza Wollnego Był sobie król czy cykl Elżbiety Cherezińskiej Odrodzone królestwo.
} 
2020). Ich napływ(z powodów politycznych lub/i ekonomicznych) budzi niepokój, zwłaszcza w kontekście walki o miejsce na rynku pracy. Atmosferę wrogości dodatkowo podsycają media, dość jednostronnie ukazując wspólną trudną przeszłość historyczną. Wydawać by się mogło, że Polskę i Ukrainę raczej więcej łączy niż dzieli, jednak postawy wrogości, może nie dominujące, ale z pewnością bardziej zauważalne, dość skutecznie demonizują wizerunek imigrantów zza wschodniej granicy ${ }^{5}$. Warto mieć na uwadze, iż Ukraińcy często przybywają do Polski z całymi rodzinami, z dziećmi, które stają przed koniecznością odnalezienia się w realiach polskiej szkoły. Naturalnie wraz z nimi obok polskich uczniów w ławkach zasiadają też dzieci innych narodowości, a od nowych kolegów odróżnia je nie tylko język i tradycja, ale także wyznanie. Dla obu stron, zarówno nowo przybyłych, jak i rodzimych mieszkańców Polski, jest to sytuacja dość trudna, dlatego uczniowie potrzebują oparcia w dorosłych. Szkoła i dom rodzinny są zobowiązane do kształtowania w swoich podopiecznych postaw poszanowania dla inności - zarówno w odniesieniu do odmienności rasowej, religijnej czy narodowościowej, jak i różnic w sposobie bycia czy postrzegania świata. Jak zauważa Bogdan Walczak, wielokulturowość nie stanowi zagrożenia dla polskości. Rzeczpospolita funkcjonowała przez wiele stuleci jako państwo wielonarodowe i to wówczas przeżywała okres największej świetności. Badacz zwraca również uwagę na nieuzasadniony warunek przynależności do narodu polskiego rozumiany jako „wspólnota krwi”, co prowadzi do umniejszenia roli „Polaków z wyboru”. Jak się bowiem okazuje, najsłynniejsi bohaterowie narodowi nie zawsze spełniają te wymagania (Walczak 2017, 41-48).

Warto zauważyć, że dzisiejsza, niestety coraz powszechniejsza postawa w najlepszym razie zdystansowania, w najgorszym otwartej wrogości wobec „innego”, nawet w II RP nie osiągała tak poważnej skali, a w każdym razie nie determinowała polityki oświatowej. Jędrzejewiczowska wizja szkoły zmierzała do zintegrowania zwaśnionego społeczeństwa, jej siłą spajającą nie ustanowiono jednak wspólnego nieprzyjaciela. Znalazło się w niej zatem miejsce nie tylko dla literatury narodowej, ale także powszechnej, głównie zachodnioeuropejskiej. Absolwent zyskiwał w związku z tym świadomość, że literatura i kultura polska nie funkcjonują w próżni, ale są wypadkową międzynarodowych wpływów (Wnuk 2008). Ówcześni reformatorzy rozumieli też doskonale, że wewnętrzna różnorodność, o ile nie prowadzi do konfliktów i rozłamu, może stanowić o sile i bogactwie dorobku narodowego. Stąd właśnie tak istotna okazała się refleksja nad regionalizmem jako jednym z głównych komponentów wizji kształcenia. Dbałość o nabycie przez uczniów rzetelnej wiedzy na temat ich małych ojczyzn nie stała w sprzeczności z fundamentem reformy - wychowaniem społeczno-obywatelskim, ale stała się jego doskonałym uzupełnieniem. Obowiązek

${ }^{5}$ Skutkiem są działania dyskryminacyjne, opisane precyzyjnie w raporcie: Tyma P., (red.) Mniejszość ukraińska i migranci z Ukrainy w Polsce, Warszawa 2018, dostępnym w Internecie: http://naszwybir.pl (dostęp: 04.08.2020). 
kształcenia regionalnego zaakcentowano w ustawie z 11 marca 1932 (Dz.U. $1932 \mathrm{nr} 38$ poz. 389). Postulat ten doczekał się rozwinięcia w nowej odsłonie gimnazjów, tj. w 1999 roku, zarówno w proponowanych lekturach, jak i w postaci ścieżek edukacyjnych (Dz.U. 1999 nr 14 poz. 129).

Warto podkreślić, że edukacja regionalna doczekała się docenienia także przez ostatnich reformatorów i znalazła swoje miejsce w nowej Podstawie programowej z języka polskiego. W obecnej formule dokumentu przypisuje się ją głównie do obszaru samokształcenia. Niestety dla edukacji antydyskryminacyjnej (czy choćby literatury powszechnej!) nie znaleziono już wiele przestrzeni. Trudno zrozumieć przyczyny tego niedopatrzenia, jednak w obliczu narastającego antagonizmu wobec szeroko rozumianej inności, szkolny kanon zdecydowanie domaga się dopełnienia w postaci stosownych rekomendacji lekturowych. Nierozsądnie byłoby pokładać wszelkie nadzieje w zbawczą moc literatury, dlatego za nie mniej istotne należy uznać rzetelne przygotowanie nauczycieli do podejmowania działań profilaktycznych ograniczających ryzyko objawów agresji. Jak się okazuje, polskie szkolnictwo wciąż ma w tej kwestii jeszcze wiele do nadrobienia.

\section{Postawa ofiarności a rola ofiary}

Ostatni raport z badania PISA, przeprowadzonego w 2018 roku, unaocznił poważne zaniedbania w zakresie zapobiegania przemocy w szkole. Okazuje się, że chociaż skala szeroko rozumianego prześladowania doświadczanego przez uczniów wzrosła od ostatniej edycji badania (tj. od 2015 roku) niemal we wszystkich państwach biorących udział w badaniu, zjawisko dręczenia $\mathrm{w}$ polskich szkołach występuje $\mathrm{z}$ większą częstotliwością niż średnia dla krajów OECD. Wspomniana negatywna tendencja może wynikać z modyfikacji instrukcji zawartej w kwestionariuszu - w jej najnowszej wersji po raz pierwszy pojawiła się wskazówka, aby badany odniósł się nie tylko do sytuacji doświadczanych w bezpośrednim kontakcie, ale także w przestrzeni wirtualnej. Wyjaśnienie to jednak w żaden sposób nie uspokaja, a wręcz przeciwnie - jest dowodem na niską świadomość piętnastolatków na temat cyberprzemocy. Przygnębiająco nastraja też kolejny wniosek przedstawiony w raporcie dotyczący stosunku piętnastolatków do aktów agresji, jakich są świadkami. Uczniowie biorący udział w badaniu zostali poproszeni o wyrażenie swojej aprobaty (lub jej braku) wobec różnych zachowań. Co prawda różnice między wynikami polskimi respondentów a ich rówieśników z innych krajów OECD nie przekroczyły kilku punktów procentowych, jednak odpowiedzi naszych gimnazjalistów świadczyły o większej akceptacji dla dręczenia oraz o mniejszym przekonaniu o konieczności stawania w obronie ofiar (Sitek 2019). Raport ukazuje zatem przykrą zależność wpisaną w funkcjonowanie wielu polskich szkół: im częściej młodzi ludzie doświadczają aktów przemocy lub je obserwują, tym bardziej są z nimi pogodzeni i uznają je za nieodzowny element 
codzienności, co jednocześnie odbiera im wiarę w skuteczność wyrażania sprzeciwu.

Każdego roku inicjuje się projekty i kampanie społeczne, mające na celu promowanie właściwych postaw wśród uczniów, rodziców i nauczycieli wobec dręczenia oraz proponujące rozmaite formy wsparcia dla osób nim dotkniętych. Są to jednak akcje podejmowane najczęściej przez organizacje non profit lub - na znacznie mniejszą skalę - działania oddolne prowadzone przez niewielkie grupy nauczycieli. Wciąż brakuje solidnych rozwiązań systemowych, które nie tylko przedstawią sprawcom oraz pedagogom przechodzącym obojętnie obok krzywdy podopiecznego konsekwencje ich postępowania, ale także wskażą możliwe rozwiązania tego problemu na jego wczesnym etapie, nie dopuszczając do eskalacji przemocy.

Mogłoby się wydawać, że nowa Podstawa programowa wychodzi naprzeciw tym oczekiwaniom. W preambule czytamy bowiem: „Szkoła zapewnia bezpieczne warunki oraz przyjazną atmosferę do nauki, uwzględniając indywidualne możliwości i potrzeby edukacyjne ucznia” (Dz.U. z 2017 r. poz. 59). Co prawda zapis wydaje się bardzo ogólny i nie precyzuje w żaden sposób działań, jakie należy podjąć, by uczynić szkołę miejscem przyjaznym i bezpiecznym, jednak nie ulega wątpliwości, iż wrogość między uczniami i będące jego naturalnym następstwem zachowania przemocowe nie sprzyjają temu celowi. Chcielibyśmy zatem założyć, iż zapis w preambule stanowi tylko wstęp do konkretnych propozycji przeciwdziałania aktom dyskryminacji w szkole. Dalej czytamy:

Kształcenie ogólne w szkole podstawowej ma na celu:

1. wprowadzanie uczniów w świat wartości, w tym ofiarności, współpracy, solidarności, altruizmu, patriotyzmu i szacunku dla tradycji, wskazywanie wzorców postępowania i budowanie relacji społecznych, sprzyjających bezpiecznemu rozwojowi ucznia (rodzina, przyjaciele);

2. wzmacnianie poczucia tożsamości indywidualnej, kulturowej, narodowej, regionalnej i etnicznej;

3. formowanie u uczniów poczucia godności własnej osoby i szacunku dla godności innych osób(...)

11. kształtowanie postawy otwartej wobec świata i innych ludzi, aktywności w życiu społecznym oraz odpowiedzialności za zbiorowość;(Dz.U. z 2017 r. poz. 59) [podkreślenia K. B]

W tym fragmencie zawarte są postulaty wychowania człowieka zatroskanego o wspólne dobro, odnoszącego się z szacunkiem do własnego dziedzictwa narodowego, kulturowego, regionalnego i etnicznego. Szacunek okazuje się zresztą wartością dominującą. Jak zauważyła Dorota Klus-Stańska, słowo to pojawia się w podstawie z 2017 roku aż 51 razy, wypierając przy tym w dużym stopniu „odwagę” i eliminując całkowicie „sprzeciw” (Klus-Stańska 2017), co może dziwić w zestawieniu z „rozwijaniem 
umiejętności krytycznego i logicznego myślenia, rozumowania, argumentowania i wnioskowania" (Dz.U. z 2017 r. poz. 59).

Taka dysproporcja budzi pewien niepokój. Postulaty twórców podstawy dotyczą przede wszystkim poszanowania dorobku rodzimej kultury, dzieje się to jednak kosztem tak elementarnej kwestii jak szacunek do samego siebie. Próżno również doszukiwać się w niej dążenia do wychowania człowieka tolerancyjnego. W tych kategoriach można potraktować co prawda zapis o „kształtowaniu postawy otwartej wobec świata i innych ludzi”, jednak jest on na tyle ogólnikowy, że rodzi obawę o nadużycia czy wypaczenia, a wystarczyłoby uzupełnienie go o fragment o otwartości również wobec innych wyznań, tradycji oraz kultur.

Model pożądanych postaw i wartości, jakimi powinien kierować się uczeń w szkole podstawowej, stawia potencjalne ofiary aktów dyskryminacyjnych na przegranej pozycji. Autorzy podstawy w żaden sposób nie zachęcają nauczycieli do budowania w uczniach przekonania, że w sytuacji naruszania ich godności mają prawo powiedzieć „nie”. Oczywiście wciąż możemy liczyć na to, iż świadomy i zatroskany o swoich podopiecznych pedagog zadba o rozwinięcie niezbędnych w takich okolicznościach kompetencji. Wyobrażenie sobie kadry nauczycielskiej złożonej wyłącznie z takich członków wydaje się jednak dość utopijne, a i sami uczniowie mają niekiedy poważne zastrzeżenia wobec deklarowanej przez ich nauczycieli postawy otwartości. W najnowszym raporcie PISA odnaleźć można następujące wnioski:

66\% uczniów ma wrażenie, że nauczyciele nie szanują ich poglądów, tyle samo sądzi, że nie może wyrażać opinii, które różnią się od opinii większości, $60 \%$ nie dostrzega tego, żeby nauczyciele, omawiając jakiś problem, ukazywali go z kilku różnych stron, 54\% uczniów sądzi, że nie może się otwarcie nie zgadzać z nauczycielem. Tyle samo jest przekonanych, iż nauczyciele dają większą swobodę wyrażania własnego zdania uczniom dobrym niż słabszym. To oczywiście jest punkt widzenia uczniów, nawet jeśli nie zawsze jest on zgodny ze stanem rzeczywistym, to jednak oddaje atmosferę podczas lekcji. Z jednej strony widzą oni, że nauczyciele zachęcają ich do wymiany poglądów na lekcjach, z drugiej jednak strony więcej niż połowa ma odczucie, iż ich opinie nie są szanowane, a nauczyciele mimo pozorów dyskusji narzucają gotowe (własne) myśli (Sitek, 2019)[podkreślenia K.B.].

Trudno zatem dziwić się, że uczniowie uznają wykluczenie i napiętnowanie wszelkiego rodzaju odmienności za naturalne, gdy sami często skazani są na odrzucenie, kiedy reprezentują pogląd rozbieżny z oczekiwaniami nauczyciela. Nie ma skuteczniejszej formy wychowania niż dobry przykład, a gdy jego zabraknie, z pozoru niewinne przyzwolenie na odbieranie niektórym członkom grupy głosu może przerodzić się w zachowania dyskryminacyjne wymierzone nie tylko w mniejszości narodowe, ale też wyznaniowe czy seksualne. Wrogość wobec inności, jak udowadniają przybierające na sile coraz to nowe konflikty społeczne w naszym kraju, nie jest 
niestety zjawiskiem marginalnym, toteż warto byłoby zaakcentować w podstawie programowej postulat przeciwdziałania im.

\section{Podsumowanie}

Choć rozwiązania i koncepcje oświatowe ukształtowane w dwudziestoleciu międzywojennym w znacznej mierze okazały się skuteczne, dziś nie mogą być bezrefleksyjnie powielane, mimo że obecna rzeczywistość zdradza pewne podobieństwo do problemów, z jakimi zmagało się polskie społeczeństwo 100 lat temu. Należy jednak pamiętać, że dzisiejsze trudności wyrastają z odmiennych przyczyn, a zatem wymagają podjęcia innych strategii naprawczych. Wśród nich najbardziej palącą kwestią wydają się: brak zrozumienia dla inności oraz obojętność na zachowania przemocowe.

Odgórne zapisy regulujące działania edukacyjne nie odnoszą się do tego niepokojącego zjawiska. Nic nie zapowiada też zmiany w tej materii, co nie oznacza, że nauczyciel w konfrontacji ze wspomnianymi trudnościami jest pozostawiony sam sobie. Z pomocą przychodzi mu m.in. rzetelnie przygotowany przez Stowarzyszenie „Otwarta Rzeczpospolita” poradnik Jak uczyć tolerancji?, zawierający materiały dydaktyczne i scenariusze zajęć dostosowane do każdego etapu edukacyjnego. Twórcy publikacji proponują różnorodne metody unaocznienia, czym są dyskryminacja, stereotypizacja czy mowa nienawiści. Uświadamiają także, jak istotna obok działań profilaktycznych okazuje się postawa nauczyciela, jego czujność oraz zdecydowane reakcje wobec wszelkich incydentów przemocowych i wykluczających. Niewątpliwym wsparciem w ramach kształcenia młodego człowieka w duchu otwartości są także projekty realizowane przez Centrum Edukacji Obywatelskiej: Szkoła Tolerancji czy Nienawiść. Jestem przeciw. W ich ramach we współpracy m.in. z Fundacją Dajemy Dzieciom Siłę powstał cykl webinariów, poświęcony zjawisku cyberprzemocy oraz sposobom jej przeciwdziałania, zaś wsparcie Europejskiego Centrum Wergelanda zaowocowało kolejną, niezwykle cenną publikacją w postaci zbioru scenariuszy zajęć uwrażliwiających na wszelkie przejawy nienawiści i nietolerancji ${ }^{6}$. Autorzy projektów poświęcają wiele uwagi z pozoru nieszkodliwym wyrażeniom i zachowaniom zakorzenionym w naszej codzienności, noszącym jednak znamiona marginalizacji lub wartościowania konkretnych grup społecznych. Uzmysławiają tym samym, że zjawisko dyskryminacji i przemocy nie rodzi się nagle, lecz rośnie stopniowo karmione obojętnością i brakiem świadomości. Przed każdym wychowawcą stoi więc ogromne wyzwanie, któremu niezwykle trudno podołać bez odpowiedniego wsparcia. Nim zatem doczekamy się reformy szkolnictwa na miarę aktualnych potrzeb, warto czerpać z wymienionych wyżej inicjatyw pełnymi garściami.

\footnotetext{
${ }^{6}$ Wspomniane materiały można obejrzeć bezpłatnie na stronie https://szkolatolerancji.ceo.org. pl/nienawisc-jestem-przeciw/materialy.
}

Polonistyka. Innowacje

Numer 12,2020 


\section{Bibliografia}

Rozporządzenie Ministra Edukacji Narodowej z dnia 15 lutego 1999 roku w sprawie podstawy programowej kształcenia ogólnego. (Dz.U. $1999 \mathrm{nr} 14$ poz. 129), http://isap.sejm.gov.pl/isap.nsf/download.xsp/WDU19990140129/O/ D19990129 01.pdf (dostęp: 12.08.2020).

Rozporządzenie Ministra Edukacji Narodowej z dnia 14 lutego 2017 r. w sprawie podstawy programowej wychowania przedszkolnego oraz podstawy programowej kształcenia ogólnego dla szkoły podstawowej, w tym dla uczniów z niepełnosprawnością intelektualną w stopniu umiarkowanym lub znacznym, kształcenia ogólnego dla branżowej szkoły I stopnia, kształcenia ogólnego dla szkoły specjalnej przysposabiającej do pracy oraz kształcenia ogólnego dla szkoły policealnej (Dz.U. z 2017 r. poz. 59), https://isap.sejm. gov.pl/isap.nsf/download.xsp/WDU20170000059/T/D20170059L.pdf (dostęp: 12.08.2020).

Ustawa z dnia 17 marca 1921 r. - Konstytucja Rzeczypospolitej Polskiej (Dz.U. $1921 \mathrm{nr} 44$ poz. 267), http://isap.sejm.gov.pl/isap.nsf/download.xsp/ WDU19210440267/O/D19210267.pdf (dostęp: 23.10.2020).

Statystyka migracji na mapie Polski, Urząd do Spraw Cudzoziemców 2019, https://migracje.gov.pl/statystyki/zakres/polska/typ/dokumenty/widok/mapal $\mathrm{rok} / 2020 / ? \mathrm{x}=0.3301 \& \mathrm{y}=0.9359 \&$ level $=1$ (dostęp: 12.08.2020).

Ustawa z dnia 11 marca 1932 r. o ustroju szkolnictwa (Dz.U. $1932 \mathrm{nr} 38$ poz. 389, http://isap.sejm.gov.pl/isap.nsf/DocDetails.xsp?id=WDU19320380389 (dostęp: 12.08.2020).

Biedrzycki Krzysztof, 2017, Sam Mickiewicz nie zrobi z nas dobrych Polaków, rozm. przepr. Kaszczyszyn O., Wielgus A., https://klubjagiellonski. pl/2017/01/04/biedrzycki-sam-mickiewicz-nie-zrobi-z-nas-dobrych-polakow (dostęp: 12.08.2020).

Dorczak Robert, 2019, Wokół reformy edukacji z 2017 roku - Krytyczna Analiza Dyskursu, Kraków, https://isp.uj.edu.pl/documents/2103800/139368467/ Wok\%C3\%B3\%C5\%82+reformy+edukacji $+z+2017+$ roku+\%E2\%80\%93+ Krytyczna+Analiza+Dyskursu/2150180a-0cb8-4da7-8495-765ebfff16d9 (dostęp: 08.08.2020).

Gałaś Mieczysław, 2020, Obustronna zależność. Patriotyzm w teorii kultury Stanisława Ossowskiego, „Refleksje”, nr 1.

Grabowska Wanda, 1969, Jędrzejewiczowska ustawa szkolna z 1932 roku, „Rozprawy z Dziejów Oświaty”, nr 12.

Grzywna Józef, 1975, Reforma jędrzejewiczowska w województwie kieleckim w opinii publicznej w latach 1932-1935, „Rocznik Muzeum Świętokrzyskiego", nr 9.

Handke Mirosław, 2019, Od września będzie dramat, rozm. przepr. Łepkowski P., „Rzeczpospolita”, https://www.rp.pl/Rzecz-o-polityce/306189911-Miroslaw-Handke-Od-wrzesnia-bedzie-dramat.html (dostęp: 12.08.2020).

Karkut Dorota, 2019, Zdaniem polonistów - reforma w szkole podstawowej w świetle badań własnych, „Annales Universitatis Paedagogicae Cracoviensis. Studia Ad Didacticam Litterarum Polonarum Et Linguae 
Szkoła na miarę czasów... tylko których? - o reformie szkolnictwa z 2017 roku

Polonae Pertinentia”, 10 (285), https://czasopisma.up.krakow.pl/index.php/ dlp/article/view/6981 (dostęp: 12.08.2020).

Klus-Stańska Dorota, 2017, Uwagi do podstawy programowej kształcenia ogólnego dla szkoły podstawowej, Gdańsk, http://edukacjananowo.pl/wp-content/ uploads/2017/02/UWAGI-DO-PODSTAWY-PROGRAMOWEJ-KSZTA\%C5\%81CENIA-OG\%C3\%93LNEGO-DLA-SZKO\%C5\%81Y-PODSTAWOWEJ.pdf (dostęp: 14.08.2020).

Korzeniowska Wiesława, 2004, Edukacja i wychowanie różnych warstw społecznych na ziemiach polskich: od drugiej połowy wieku XIX do roku 1918, Kraków.

Krawiec Beata, 2018, Ciagłość/zmiana/nieciagłość w edukacji. Ujęcie komparatystyczne, w: Komunikacja a zmiana społeczna, Kędzior J., Krawiec B., Biedroń M., Wrocław, http://bibliotekacyfrowa.pl/Content/89649/Komunikacja_a zmiana_spoleczna_biblioteka_cyfrowa.pdf (dostęp: 10.08.2020).

Osiński Sławomir, 2018, Reformy stulecia, „Refleksje”, nr 6.

Magiera Elżbieta, 2018, Jak się zmieniała szkoła w Polsce?, rozm. przepr. Iwasiów S., „Refleksje”, nr 6.

Sadura Przemysław, 2012, Raport Fundacji Amicus Europae Szkoła i nierówności społeczne. Diagnoza zjawiska i propozycja progresywnej polityki edukacyjnej w Polsce, Warszawa, http://www.feswar.org.pl/fes2009/pdf doc/ raport-3.pdf (dostęp: 24.10.2020).

Sitek Michał (red.), 2019, Program Międzynarodowej Oceny Umiejętności Uczniów. Wyniki badania PISA 2018 w Polsce, Warszawa, https://pisa.ibe. edu.pl (dostęp:12.08.2020).

Tomaszewska Grażyna, 2016, Edukacja polonistyczna w perspektywie najnowszych zmian, „Polonistyka. Innowacje”, nr 4.

Tyma Piotr (red.), 2018, Mniejszość ukraińska i migranci z Ukrainy $w$ Polsce, Warszawa, https://www.rpo.gov.pl/sites/default/files/Raport\%20\%27Mniejszo\%C5\%9B\%C4\%87\%20ukrai\%C5\%84ska\%20i\%20migranci\%20z\%20Ukrainy\%20w\%20Polsce.\%20Analiza\%20dyskursu\%27_0.pdf (dostęp: 4.08.2020).

Walczak Bogdan, 2017, Edukacja polonistyczna w kontekście obecnej polityki historycznej, w: Edukacja polonistyczna. Metamorfozy kontekstów i metod, Karwatowska M., Tymiakin L. (red.), Lublin.

Wnęk Jan, 2008, Problemy polskiego szkolnictwa zaboru pruskiego i rosyjskiego na kartach „Szkoły” 1868-1914, „Biuletyn Historii Wychowania”, nr 24.

Wnuk Alina, 2008, Problematyka europejska $w$ polonistyce szkolnej lat 1926 1939, „Acta Universitatis Lodziensis. Folia Litteraria Polonica”, nr 10, Łódź.

\section{O Autorce}

Katarzyna Błaszczyk - absolwentka filologii polskiej na Wydziale Polonistyki Uniwersytetu Jagiellońskiego, studentka Szkoły Edukacji PAFW i UW. Doświadczenie nauczycielskie zdobywała w projekcie Centrum Nauczania Domowego, udzielając wsparcia uczniom w edukacji domowej. W ramach projektów Polonijka Polonijna Szkoła Podstawowa oraz Polskie 
Szkoły Internetowe Libratus pracowała z dziećmi polonijnymi z całego świata. Zainteresowania badawcze autorki koncentrują się wokół edukacji alternatywnej oraz polityki oświatowej.

Polonistyka. Innowacje Numer 12, 2020 